\title{
A combined technique using SEM and TOPSIS for the commercialization capability of R\&D project evaluation
}

\author{
Charttirot Karaveg $^{\mathrm{a}^{*}}$, Natcha Thawesaengskulthai ${ }^{\mathrm{b}}$ and Achara Chandrachai ${ }^{\mathrm{c}}$
}

${ }^{a}$ PhD Candidate, Technopreneurship and Innovation Management Program, Chulalongkorn University, Bangkok, Thailand ${ }^{b}$ Associate Professor, Industrial Engineering Department, Faculty of Engineering, Chulalongkorn University, Bangkok, Thailand 'Professor Emeritus, Technopreneurship and Innovation Management Program, Chulalongkorn University, Bangkok, Thailand

\section{H R O N I C L E}

\begin{tabular}{l}
\hline Article history: \\
Received December 10, 2014 \\
Received in revised format: \\
March 2, 2015 \\
Accepted March 23, 2015 \\
Available online \\
March 25 2015 \\
\hline Keywords: \\
Commercialization capability \\
R\&D evaluation criteria \\
Project selection \\
SEM \\
MCDM \\
AHP \\
TOPSIS
\end{tabular}

\section{Introduction}

$R \& D$ investment is the key of creating knowledge and gaining a competitive advantage. This particularly applies to the global strategy of organization with small and medium enterprises (SMEs). Therefore, R\&D is one of the most important indicators at innovation level) Raymond \& St-Pierre, (2010. R\&D investment in Thailand has been at a low level for the last decade (GERD/GDP $=0.024 \%$ ).

* Corresponding author.

E-mail address: charttirot@gmail.com, charttirot@swu.ac.th (C. Karaveg)

(C) 2015 Growing Science Ltd. All rights reserved.

doi: 10.5267/j.dsl.2015.3.004

\footnotetext{
C. $10.52671 . d \mathrm{~s} .2015 .3 .004$
} 
Moreover, $60 \%$ of the research production is the responsibility of governmental section (TSI, 2013). Currently, the interaction between the technology owners and technology transferees is absent, only the transfer level which focuses on machines and equipment than knowledge transfer, is present (Miller et al., 2011). Numerous R\&D transfers have not been successful because the nature of innovation itself, which is uncertain and difficult to predict, especially so for radical innovation (Herath \& Bremser, 2005). To deal with innovation, one has to rely on professional and risk-based decision )Tidd \& Besssant, (2009. Previous research has focused on proposing a model to monitor the R\&D process as a Performance Measurement System (PMS) and setting key performance indicators (KPIs) (Agostino et al., 2012; Chiesa et al., 2009). However, the ability to make perceptions of R\&D's ability to be commercialized, the ranking of each criterion, and the managerial tools to support decision makers are still lacking.

R\&D project selection becomes a multi-criteria decision-making problem. Many MCDM methods have been proposed for the best alternative selection in various R\&D contexts such as resource allocation in the industrial R\&D environment (Liberatore, 1987), project termination (Liang, 2003), financial information of R\&D project (Collan \& Luukka, 2013), and scientific research capability (Liu \& Shi, 2009). One of the most widely used MCDM methods is the Analytic Hierarchy Process (AHP), which uses the hierarchical structure and relative ranking of alternatives. Another noted technique is that of Technique for Order Preference by Similarity to Ideal Solution (TOPSIS) (Karimi et al., 2012). The mixed-method approach of these two techniques has been proposed by many researchers )Büyüközkan \& Çifçi, 2012; Gangurde \& Akarte, 2013; Singh \& Kumar, (2013. In the main concept of the AHPTOPSIS method, AHP is used to determine the weight of the criteria and TOPSIS to compare the alternatives to reduce the number of paired comparisons arising from AHP (Parsaeia et al., 2014). This comes about as AHP is based on the subjective judgment, perception and expertise of the decisionmaker (Salehi, 2015). To overcome these problems SEM is used as a powerful tool in empirical research. Punniyamoorty et al. (2012) proposed the SPM technique, which uses both SEM and AHP. SEM is used to identify the criteria, sub-criteria and weighting. AHP is used to rank each decision alternative. This mixed method can optimize the selection power and decrease the limits of each method. SEM can confirm the relationship among the indicators, improve the accuracy of indicators loading and reduce the number of calculation processes. On the other hand, AHP can reduce the effect of the inconsistency of the decision-maker's opinion. In this study, we prefer TOPSIS to calculate the alternative score of expert opinion instead of using AHP since the former shows better performance in reducing decision cycle time (Gangurde \& Akarte, 2013). Moreover, to the best of the researcher's knowledge, there is currently no research applying SEM and TOPSIS.

The development of R\&D commercialization capability criteria and a combined technique of SEM and TOPSIS is vital to assist R\&D manager, researcher and entrepreneur in selecting high commercially potential projects. Hence, the paper aims to establish a SEM-TOPSIS technique and comprehensive assessment criteria for evaluating $R \& D$ project commercialization capability or tollgate coherent with the Stage-Gate process. This would ensure R\&D commercialization was more effective and prevent a resource meltdown, which is highly beneficial for project management and strategy adjustment. The developed technique and the conceptual framework for R\&D commercialization capability were synthesized to answer the research questions as follows: Firstly, what are the criteria to assess the R\&D commercialization capability? Secondly can the combination of SEM and TOPSIS evaluate an R\&D project?

\section{Theoretical and conceptual background}

\subsection{R\&D Commercialization criteria}

Prior research related to $R \& D$ evaluation suggested that $R \& D$ commercialization criteria could be conceived as a set of six main elements as described below. 


\subsubsection{Technology}

The early stage of technological evaluation focused on technological feasibility (e.g. functional design, operating condition, and standardization) (Frederick \& Kuratko, 2010) together with technology compatibility (e.g. complications, manufacturing process) (Liao et al., 2007) the benefits were considered by cost reduction and productivity (Coccia, 2003). The research failure on scale-up phases raises the need for assessing the Technology Readiness Level (TRL) which consists of nine levels from basic principle to successful operations (Graettinger et al., 2002; United States Department of Energy, 2011). In the prototype phase the technology is considered with several factors in mind, such as; comparative advantage, technology beneficial in terms of value to consumer, technology lifetime, and technology applicability (Boyack \& Rahal, 2005; Chiesa et al., 2009; Gemünden et al., 2007).

\section{$H_{1}$ : Technology potential will be associated with $R \& D$ commercialization capability}

\subsubsection{Marketing}

Marketing attributes should be studied five years in advance to calculate the success opportunity and risk, strategy determination, and business plan by market analysis. Addressing this area requires finding the necessary information such as economic trends, and competitive data (Frederick \& Kuratko, 2010), as well as considering the products values, such as uniqueness, changing consumer behavior, imitation, and value chain (Gemünden et al., 2007; Verbano \& Nosella, 2010). Paun (2011) proposed Demand Readiness Levels (DRL's) based on market pull theory to provide the information for decision making such as consumer need, expected functionalities, and competencies.

\section{$H_{2}$ : Marketing potential will be associated with $R \& D$ commercialization capability}

\subsubsection{Financial}

Several researchers measure the level of successfulness of $R \& D$ projects by considering financial information such as production cost, sales volume, source of funds (Frederick \& Kuratko, 2010). These enable correct forecasts of the returns such as; net present value (NPV), rate of return (ROI), internal rate of return (IRR) )Verbano \& Nosella, (2010. There is also an effort to adapt the traditional financial techniques in order to evaluate projects. Real option techniques decrease the risks and uncertainty in the long run together with increasing income from the products and share value. (Callen et al., 2010; Herath \& Bremser, 2005; Nigro, Morreale, \& Enea, 2014). Also, calculation for reflecting the accurate R\&D value over time (Kwak \& Dixon, 2008; Yongjian et al., 2008).

\section{H3: Financial potential will be associated with $R \& D$ commercialization capability}

\subsubsection{Intellectual property}

Know-how and patent are importance intellectual capital because they can create a comparative advantage for organization (Byers et al., 2011). IP valuation is the key driver of innovation transfer. The valuation methods are; Cost approach, Income approach, and Market approach. The R\&D evaluation should be conducted together with an IP search, IP portfolio, and patent mapping to detect patent-ability including on novelty and freedom to operate (FTO) (Apperson et al., 2005). The factors affecting the value of intellectual properties has to be considered, these include IP law, IP exploitation, and IP enforcement, which must also be considered substitute technology, and difficulty-ease in the development and approval stage (Jungwook et al., 2009).

\section{$H_{4}$ : Intellectual potential property will be associated with $R \& D$ commercialization capability}




\subsubsection{Resource}

Resource - Based View (RBV) theory focuses on the strategy of internal resource control to create sustainable competition. Both tangible resources (Wernerfelt, 1984) and intangible resources (Teece, 2010) are considered. The intangible capital includes potential employees, managerial skills, customer relation management, suppliers, knowledge management )Byers et al., (2011 and human resource management (HRM) practices (Popaitoon \& Siengthai, 2014). The criteria for applying commercial application on resources includes personal competency and interaction, such as trust and giving honor, and clear goals (Somsuk et al., 2010). Communication among R\&D members has positive effect on exchanging tacit knowledge and increase the success rate of R\&D project (Plewa et al., 2013).

\section{$H_{5}:$ Resource potential will be associated with $R \& D$ commercialization capability}

\subsubsection{Impact of $R \& D$ utilization}

A comprehensive evaluation of potential R\&D should compare financial performance with the nonfinancial performance )NFP) (Cardinaels \& Veen-Dirks, 2010) through defining clear aims and objectives; identifying requirements; evaluation of the successfulness of activities and utilize resources information (Kulatunga et al., 2007). Learning process is the key to innovative organization (Tidd \& Besssant, 2009) and knowledge transfer creates the connection between University and Industry) Plewa et al., .(2013This will lead to improve innovation capacity (e.g. R\&D usage, learning process) (Chiesa et al., 2009; Mu \& Benedetto, 2011). Moreover, the R\&D evaluation can be used to follow the conduction of R\&D projects through effective project management and providing feedback for future improvements) Kulatunga et al., 2011; Stanley et al., (2010. Innovation learning and Networks (Lazzarotti et al., 2011), user's satisfaction (Cardinaels et al., 2010) and sustainability (Amini \& Bienstock, 2014) play important roles.

$H_{6}$ : Impact potential of $R \& D$ utilization will be associated with $R \& D$ commercialization capability

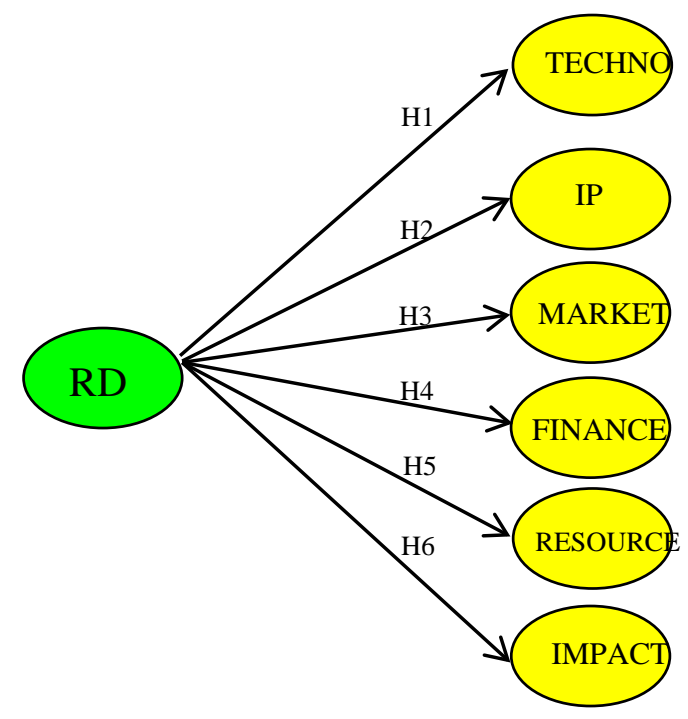

Fig. 1. Base model

\subsection{R\&D selection using MCDM methods.}

In the R\&D context, Liang (2003) used AHP for the evaluation of project termination or continuation, which is based on the benchmarking method. Wang et al. (2005) applied AHP to evaluate the outcome of multidisciplinary R\&D project, while Yu et al. (2008) proposed the expert's performance evaluation to assess a technological project. Banwet and Deshmukh (2008) developed an integrated DEA-AHP to 
evaluate the R\&D project performance. As concerns selecting the R\&D project, Mohanty et al. (2005) applied ANP along with financial information.

Another popular MCDM technique is the Technique for Order Preference by Similarity to Ideal Solution (TOPSIS). Collan and Luukka ((2013 used discounted cash flow (DCF) for ranking R\&D projects, while Liu and Shi (2009) proposed an evaluation model of university scientific research capability. More specifically, Tan et al. (2010) applied TOPSIS in construction project selection for bidding. Moreover, a combined technique of AHP and TOPSIS has been proposed by many researchers )Büyüközkan \& Çifçi, 2012; Gangurde \& Akarte, 2013; Singh \& Kumar, (2013 and widely applied in complex project selection. AHP is used to determine the weight of the criteria and TOPSIS is used to compare the alternatives to reduce the number of paired comparisons arising from AHP (Parsaei et al., 2014). AHP does not allow the relative among attribute. The solution was proposed by using ANP, which was developed from AHP by Saaty (1996). Lin and Tsai ( (2008applied ANP and TOPSIS in the selection of locations of new hospitals in China funded through foreign direct investment. Büyüközkan and Çifçi (2012) employed ANP-TOPSIS in a company's environmental performance measurement. Punniyamoorty et al. (2012) proposed the SPM technique, which used SEM and AHP in supplier selection. SEM is better than ANP in a problem concerning relative attributes because it takes the confirmatory approach to test and estimate the causal relationship using a combination of statistic data and qualitative causal assumption. In this study we used SEM to identify the criteria, sub criteria, and weighting. Also, TOPSIS was used to calculate the alternative scores of expert opinions as the technique performs better than AHP in reducing the decision making cycle.

\section{Research methodology}

The research conducted an empirical investigation that comprised of two distinct steps. The first step undertook a survey that involved 272 Thai entrepreneurs and researchers who have successfully commercialize their innovation. Data collection and analysis are described below. The second step involved a case study of $45 \mathrm{R} \& \mathrm{D}$ projects in research institutes for technique validation.

\subsection{Indicators and criteria development}

The indicators were identified by a structured in-depth interview approximately one to three hours. The respondents were asked to describe their evaluation process and indicators for evaluating R\&D commercialization. Purposing sampling with suggestions during the interview or snowball sampling is deployed to reach the fourteen participations. They were divided into six experts and eight project managers or decision makers, in eight Thai government research institutes which stipulated R\&D commercialization as their mission as follow: (1) Agricultural Research Development Agency (ARDA) (2) National Innovation Agency (NIA) (3) National Science and Technology Development Agency )NSTDA) (4) Thailand Institute of Scientific and Technological Research (TISTR) (5) National Research Council of Thailand) NRCT) (6) Thailand Research Fund (TRF) (7) National food institute (NFI) and (8) Thailand Textile Institute (THTI).

Interview results from experts reveal 45 indicators which are categorized in six criteria. After the indicators were summarized, a list of items and definitions was sent to the 14 experts to confirm the indicators. Five questionnaires were returned and item objective congruence (IOC) index was calculated to show the content validity. The returned questionnaires from five experts indicated that items 37 of 45 items have the IOC score more than 0.60 which explain high validity of its content as shown in Appendix A.

The survey research samples were entrepreneurs and researchers who have successfully commercialized their R\&D. The names were selected from the annual reports from 2007 to 2011. Eight Thai government research institutes were selected which stipulated $R \& D$ commercialization as their mission as show 
above. The questionnaire was validated for the reliability by Cronbach's alpha coefficient; it was found that the reliability is .78 to .95. The data was collected between May - September 2013 by using questionnaire. The respondents answered through email, online surveys, and telephone interviews. The response rate was 272 willing participants from the disclosed lists in the governmental research institutes which have been successful in commercializing R\&D. Factor Analysis and Structural Equation Modeling (SEM) were used to test the seven hypotheses.

\subsection{SEM-TOPSIS technique and validation}

The SEM-TOPSIS method was used to build the R\&D evaluation decision support system using PHP computer language. SEM was used to create critical criteria and weights, while TOPSIS created the rank and score of alternatives and allowed for group decision making to provide completeness of data and enhance the accuracy. The research focused on innovative firms and research institutes to assess the accuracy of the evaluation results compared to the actual commercial utilization. The sample comprised 45 commercialized R\&D projects selected by project managers, business developers and researchers with the Single Decision Support System or Group Decision Support System. The data was collected from on-site visits from January to November 2014. The tested dataset was investigated using the proposed technique to find the commercialization capability of R\&D projects. The results were then evaluated with accuracy metrics, namely, sensitivity, specificity and accuracy (Anooj, 2013). The definitions are given in Table 1.

\section{Table 1}

Sensitivity, specificity and accuracy

\begin{tabular}{|c|c|c|c|}
\hline \multirow[t]{2}{*}{$\begin{array}{l}\text { Outcome of the } \\
\text { diagnostic test }\end{array}$} & \multicolumn{3}{|c|}{$\begin{array}{l}\text { Condition } \\
\text { As determined by Standard of Truth }\end{array}$} \\
\hline & Positive & Negative & Row total \\
\hline Positive & $\mathrm{TP}$ & FP & $\begin{array}{l}\mathrm{TP}+\mathrm{FP} \\
\text { (Total number of subjects } \\
\text { with positive test) }\end{array}$ \\
\hline Negative & $\mathrm{FN}$ & $\mathrm{TN}$ & $\begin{array}{l}\mathrm{FN}+\mathrm{TN} \\
\text { (Total number of subjects } \\
\text { with negative test) }\end{array}$ \\
\hline Column total & $\begin{array}{l}\text { TP+FN } \\
\text { (Total number of subjects } \\
\text { with given condition) }\end{array}$ & $\begin{array}{l}\text { FP+TN } \\
\text { (Total number of subjects } \\
\text { without given condition) }\end{array}$ & $\begin{array}{l}\mathrm{N}=\mathrm{TP}+\mathrm{TN}+\mathrm{FP}+\mathrm{FN} \\
\text { (Total number of subjects in } \\
\text { study) }\end{array}$ \\
\hline
\end{tabular}

\section{Research Results}

\subsection{R\&D commercialization capability indicators and criteria}

\subsubsection{Descriptive statistics and Correlation analysis}

The sample distribution is as follows - entrepreneurs (83.1\%) researcher )16.9(\%; and male (60.3) female (39.7\%) bachelor degree (40.5\%); and 10 - 20 years working experiences (61\%). The annual sale rage from 600,000 to $300,000,000$ baths, but the $R \& D$ investments were on average lower than $1 \%$. Sources of R\&D were co-researched with government research institute total $45.6 \%$. More than 14 industrial sectors are represented. Further details are shown in Appendix B

\subsubsection{Factor Analysis}

Factor analysis was conducted to reduce instability due to too many indicators. Table 2 shows the value of KMO and Bartlett's Test of Sphericity is 0.50 to 0.86 and the significant level tests are 0.001 . This 
suggests that it suits a factor analysis. Sum of squared loading of six variable explained 39.78 to 68.91 per cent of total variance. The details are shown in Appendix C. To decrease the synthesis of the initial factor, the criteria matrix was rotated. The results are:

1) Technology (TECHNO): two observed variables. We name them Technology Capability (TCAP) and Technology Compatibility )TCOMP).

2) Intellectual property (IP): one observed variable which are named IP Valuation (IPVAL)

3) Marketing (MARKET): three observed variables. We name them Market Potential (MPOT), Market Strategy (MSTR), and Market Analysis (MANS).

4) Finance (FINANCE): two observed variables. We name them Financial Analysis (FANS) and Financial Return (FRETURN).

5) Resources )RESOURCE): one observed variables which are named Human Resource (HR)

6) Impacts (IMPACT): two variables. We name them Sustainability (SUST) and Innovation Capacity (IC).

\subsubsection{The second-order confirmatory factor-analysis model}

The Pearson's product moment correlation was used to test suitability for confirmatory factor analysis (CFA) of R\&D commercialization model. The observed variable can be divided into six commercial competency elements:

We found that form a total of 55 pairs of variable, 51 are significant ( $\mathrm{p}<.(05$. The correlation coefficients are 0.14 to 0.65 as shown in Table 3.

Table 2 Correlation metric

\begin{tabular}{|c|c|c|c|c|c|c|c|c|c|c|c|}
\hline & TCAP & TCOMP & IPVAL & MPOT & MSTR S & MANS & FANS & FRETURN & HR & SUST & IC \\
\hline TCAP & 1.00 & & & & & & & & & & \\
\hline TCOMP & $.32^{* *}$ & 1.00 & & & & & & & & & \\
\hline IPVAL & $.19^{* *}$ & $.16^{* *}$ & 1.00 & & & & & & & & \\
\hline MPOT & $.31^{* *}$ & $.34^{* *}$ & $.23^{* *}$ & 1.00 & & & & & & & \\
\hline MSTR & $.43^{* *}$ & $.28^{* *}$ & $.31^{* *}$ & $.55^{* *}$ & 1.00 & & & & & & \\
\hline MANS & $.14^{*}$ & $.19^{* *}$ & $.35^{* *}$ & $.24^{* *}$ & $.29^{* *}$ & 1.00 & & & & & \\
\hline FANS & $.22^{* *}$ & $.19^{* *}$ & $.42^{* *}$ & $.42^{* *}$ & $.44^{* *}$ & $.31^{* *}$ & 1.00 & & & & \\
\hline FRETURN & $.15^{*}$ & $.19^{* *}$ & $.49^{* *}$ & $.35^{* *}$ & $.35^{* *}$ & $.32^{* *}$ & $.65^{* *}$ & 1.00 & & & \\
\hline HR & $.18^{* *}$ & $.16^{* *}$ & $.14^{*}$ & $.16^{* *}$ & $.17^{* *}$ & $.20^{* *}$ & $.27^{* *}$ & $.16^{*}$ & 1.00 & & \\
\hline SUST & $.35^{* *}$ & .09 & $.18^{* *}$ & $.25^{* *}$ & $.24^{* *}$ & .06 & $.21^{* *}$ & .10 & $.26^{* *}$ & 1.00 & \\
\hline IC & $.33^{* *}$ & $.18^{* *}$ & $.16^{* * *}$ & .11 & $.28^{* *}$ & .08 & $.19^{* *}$ & $.14^{*}$ & $.23^{* *}$ & $.45^{* *}$ & 1.00 \\
\hline $\bar{X}$ & 4.01 & 4.03 & 3.12 & 4.06 & 3.86 & 2.64 & 3.67 & 3.33 & 3.53 & 3.71 & 3.85 \\
\hline S.D. & .64 & .70 & 1.11 & .619 & .611 & 1.71 & .831 & 1.21 & 1.18 & .878 & .645 \\
\hline \multicolumn{12}{|c|}{ Bartlett's Test of Sphericity $=742.31, \mathrm{p}=.000$} \\
\hline Kaiser-Meyє & -Olkin $\mathrm{N}$ & ure of Sam & ing Adec & $y=.79$ & & & & & & & \\
\hline
\end{tabular}

Table 2, Table 3 and Fig. 2 indicate that the measurement model of R\&D commercialization capability is concordant with the empirical data. It can be considered by the Chi-Square $\left(\chi^{2}=48.60\right.$; $\mathrm{df}=33$; $\mathrm{p}=$ 0.04 (GFI $=0.99$, AGFI $=0.99$ and $\mathrm{RMR}=0.05$, as well as RMSEA $=0.04$. Validity of the observed variables found that the HR variables have the maximum validity. Followed by IPVAL, FANS, MSTR, FRETURN, MPOT, IC, SUST, TCOMP, and TCAP. Whereas MANS was the variable which have the minimum validity. All 11 variables have the value as positive result. This indicates that if the consideration of the variables is taken into account, the $\mathrm{R} \& \mathrm{D}$ recruitment of commercial potentials will get high results.

When considering the factor score coefficients, it was found that all six components had the significant weight between .34 and .96 with the statistical significance is at .001 for every value. This suggests that 
the model was developed in accordance with the empirical data and the hierarchical model results (Table 5 and Fig. 4) which provide a research hypothesis with supports for H1, H2, H3, H4, H5, and H6. The standardized solution is arranged from high to low as follows: the MARKET $(\beta=0.96)$, TECHNO $(\beta=0.72)$, FINANCE $(\beta=0.68)$, IMPACT $(\beta=0.54)$, IP $(\beta=0.42)$, and RESOURCE $(\beta=$ $0.34)$. The Squared multiple correlation $\left(r^{2}\right)$ has a direct relationship with R\&D commercialization capability, 91\%, 51\%, 46\%, 28\%, 17\%, and 11\%, respectively. This indicates that the commercial competency on each component is the related and it is not separated independently. The consideration of R\&D to be applied to the commercial benefits should be carried out in all 6 aspects altogether.

Table 3

Path coefficients and fit indices

\begin{tabular}{|c|c|c|c|c|c|}
\hline Path & $\mathrm{b}(\mathrm{SE})$ & $\beta$ & $\mathrm{t}$ & $\mathrm{R}^{2}$ & FSR \\
\hline TCAP --> TOCHNO & 0.37 & 0.57 & ----- & 0.33 & 0.50 \\
\hline TCOMP --->TOCHNO & $0.41(0.08)$ & 0.59 & & 0.35 & 0.51 \\
\hline IPVAL ---> IP & 0.90 & 0.96 & ------ & 0.92 & 1.20 \\
\hline MPOT ---> MARKET & 0.45 & 0.72 & ------ & 0.52 & 0.59 \\
\hline MSTR ---> MARKET & $0.46(0.05)$ & 0.75 & $9.26 * * *$ & 0.56 & 0.60 \\
\hline MANS ---> MARKET & $0.66(0.12)$ & 0.39 & $5.50 * * *$ & 0.15 & 0.05 \\
\hline FANS ---> FINANCE & 0.74 & 0.90 & ------ & 0.80 & 0.85 \\
\hline FRETURN ---> FINANCE & $0.87(0.10)$ & 0.72 & $8.85^{* * *}$ & 0.52 & 0.25 \\
\hline HR ---> RESOURCE & 0.96 & 0.98 & ------ & 0.97 & 1.01 \\
\hline SUST ---> IMPACT & 0.56 & 0.64 & ------ & 0.41 & 0.45 \\
\hline IC ---> IMPACT & $0.45(0.10)$ & 0.70 & $4.75 * * *$ & 0.49 & 0.82 \\
\hline TOCHNO ---> RD & $0.72(0.12)$ & 0.72 & $5.76^{* * *}$ & 0.51 & \\
\hline IP ---> RD & $0.50(0.09)$ & 0.42 & $5.80 * * *$ & 0.18 & \\
\hline MARKET ---> RD & $0.96(0.10)$ & 0.96 & $9.59 * * *$ & 0.91 & \\
\hline FINANCE ---> RD & $0.68(0.08)$ & 0.68 & $9.14^{* * *}$ & 0.47 & \\
\hline RESOURCE ---> RD & $0.41(0.08)$ & 0.34 & $4.90 * * *$ & 0.11 & \\
\hline IMPACT ---> RD & $0.54(0.11)$ & 0.54 & $5.05^{* * *}$ & 0.29 & \\
\hline
\end{tabular}

Chi-square $=47.08, \mathrm{df}=33, \mathrm{P}=0.053, \mathrm{GFI}=0.97, \mathrm{AGFI}=0.94, \mathrm{RMR}=0.05, \mathrm{RMSEA}=0.73$

$* * * \mathrm{p}<.001,-----=$ constrained parameter

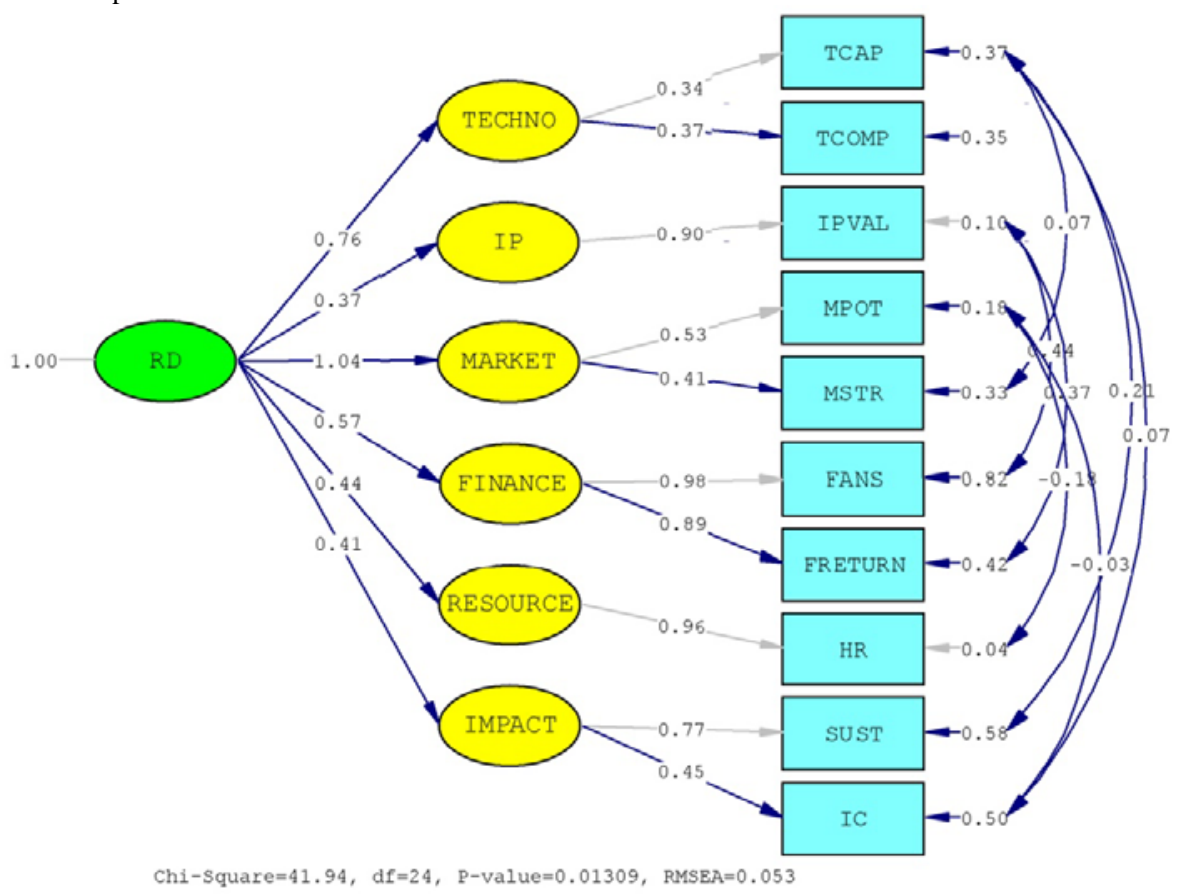

Fig. 2. Hierarchical model (path coefficients)

\subsection{SEM-TOPSIS technique}

The SEM-TOPSIS method is described below. In the first step, SEM was adopted to determine the hierarchical criteria and their relatives. The critical weights were obtained from the standardized solution in Table 3. The decision matrix of alternative performance evaluation was created by 
requesting the participants to provide a set of values within the range of one to ten for the sub-criteria. After the decision matrix was determined, the formula below was used.

$$
\begin{aligned}
& \mathrm{RD}_{1}=0.57 \text { TCAP }_{1}+0.59 \text { TCOMP }_{1}+0.96 \mathrm{IPVAL}_{1}+0.72 \mathrm{MPOT}_{1}+0.75 \mathrm{MSTR}_{1}+0.39 \\
& \text { MANS }_{1}+0.90 \mathrm{FANS}_{1}+0.72 \mathrm{FRETURN}_{1}+0.98 \mathrm{HR}_{1}+0.64 \mathrm{SUST}_{1}+0.70 \mathrm{IC}_{1}
\end{aligned}
$$

After determining the criteria and weighs, the TOPSIS ranking process was used for alternative selection. The calculation process based on Yoon and Hwnag (1995) and Lin and Tsai (2008) is presented below.

Step 2 normalize

$$
r_{k j} \frac{r_{k j}}{\sqrt{\sum_{j=1}^{m} x_{k j}^{2}}} k=1,2, \ldots, s \quad j=1,2, \ldots, m
$$

Step 3 Define the weighted normalized performance matrix

$$
\begin{aligned}
& V=\left(v_{k j}\right) \forall k, j \\
& v_{k j}=w_{j} \times r_{k j}
\end{aligned}
$$

Step 4 Identify positive-Ideal and Negative-Ideal solutions)

$$
\begin{aligned}
& V^{*}=\left\{v_{1}^{*}, v_{2}^{*}, \ldots, v_{m}^{*}\right\}=\left\{\left(\max _{k} v_{k j} \mid j \in J\right), \quad\left(\min _{k} v_{k j} \mid j \in J\right)\right\} \\
& V^{-}=\left\{v_{1}^{-}, v_{2}^{-}, \ldots, v_{m}^{-}\right\}=\left\{\left(\max _{k} v_{k j} \mid j \in J\right), \quad\left(\min _{k} v_{k j} \mid j \in J\right)\right\}
\end{aligned}
$$

Step 5 Calculate the distance between the ideal solution and the negative ideal solution for each alternative.

$$
\begin{aligned}
& S_{k}^{*}=\sqrt{\sum_{j=1}^{m}\left(v_{k j}-v_{j}^{*}\right)^{2} k=1,2, \ldots, s ; j=1,2, \ldots, m} \\
& S_{k}^{-}=\sqrt{\sum_{j=1}^{m}\left(v_{k j}-v_{j}^{-}\right)^{2} k=1,2, \ldots, s ; j=1,2, \ldots, m .} .
\end{aligned}
$$

Step 6 Calculate the relative choosiness to the ideal solution of each alternative.

$$
C_{k}^{*}=\frac{S_{k}^{-}}{S_{k}^{*}+S_{k}^{-}} \quad k=1,2, \ldots, s .
$$

Step 7 Rank the performance order.

Fig. 3 shows the interdependency network. The blue arrows are the hierarchical criteria obtained from SEM. The red arrows are the ranging structure of alternatives compared by TOPSIS. 


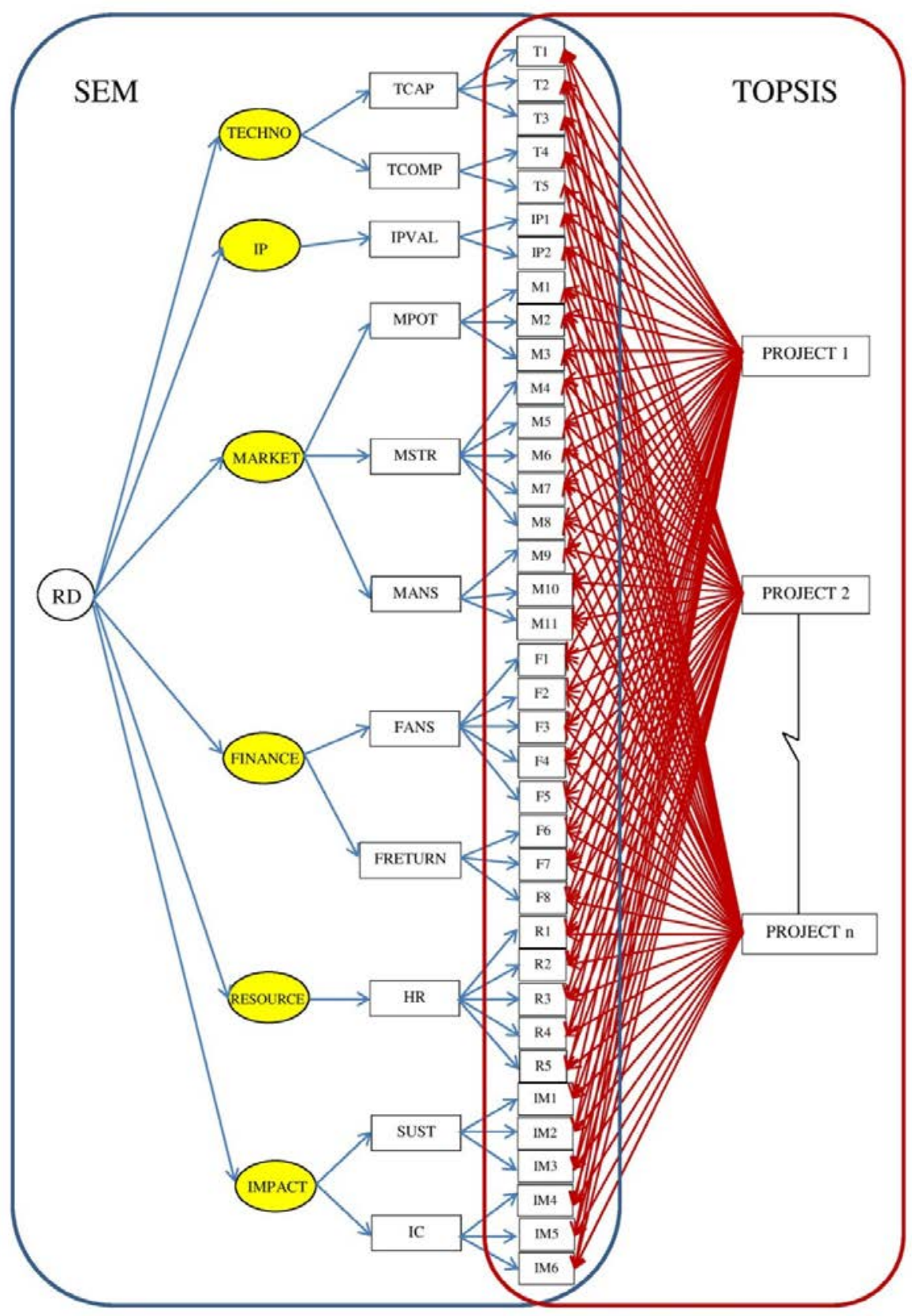

Fig. 3. SEM-TOPSIS concept

\subsection{SEM-TOPSIS technique Validation}

The accuracy test of the SEM-TOPSIS decision support system score was created by project managers, entrepreneurs, and researchers, who are the target users. The correctness of the program is 97.78 percent. The R\&D project details are provided in Appendix C. There is only one false case, of which further investigation revealed the project to be successfully commercialized because it was developed and used internally within the firm.

\section{Table 4}

Accuracy test result

\begin{tabular}{llll}
\hline \multirow{2}{*}{ Outcome } & & Condition & Total \\
\hline Positive & Positive & Negative & 41 \\
Negative & $41(100 \%)$ & 0 & 4 \\
Total & $1(25 \%)$ & $3(75(\%$ & 45 \\
\hline
\end{tabular}




\section{Conclusion and Discussion}

The research results indicate that $R \& D$ which has commercial competency has to be obtained by a minimum six crucial criteria arranged according to the significance as follows; marketing, technologies, finance, intellectual properties, resources, and impacts. Marketing data is unavoidable when considering R\&D commercialization capability because it is the assurance of innovation diffusion when the products are debuted. The second criterion is the technology. It is considering as a project fail save to avoid failure in the scale-up phase and prevent unnecessary high cost. The third criterion is the finance which explains an estimate of the investment. Based on the interview, estimated cost of an innovation which is based on many uncertainties in the long-term can causes error in the estimation. The accuracy of estimation and credibility of data resources therefore becomes the crucial factor for financial evaluation. The speculative Research should consider financial data together with nonfinancial performance )Callen et al., (2010. The evaluation on impacts. This is usually determined in policy both in terms of specification-form for the exposure of project offers as well as being part of visions and missions of the organization to respond the goals in the long terms. Sustainability creation and the increase of innovation capability are two examples. These factors might help an organization to handle sustainability-led innovation (SLI) by facilitating firm with tools and method, and developing new knowledge at system level to overcome traditional boundaries (Seebode et al., 2012). The proposed criterion includes human and sustainability issues that were absent from previous study (Vandaele \& Decouttere, 2013; Sohn et al., 2007). Intellectual property is the fifth criteria, IP valuation and royalty fees are the only significance. Thai entrepreneurs are only concerned with IP violation; while researchers care about the right of ownership. It might because the entrepreneurs in Thailand are mostly SMEs which means they do not have in-house R\&D; hence, they rely on technology developed outside firm. The last criterion is evaluation of resource with emphasize on human resources, which is coherent with somnuk et.al.(2010) research summary on the most important factor of technological R\&Dhuman resource, such as talent manager, internal expert. Han and Bae (2014) indicated that having highly skilled R\&D staff can enhance a firm’s performance.

We used Structural Equation Modeling (SEM) and Technique for Order Preference by Similarity to Ideal Solution (TOPSIS) algorithms to develop the Decision Support System (DSS) based on the R\&D commercialization indicators. The SEM-TOPSIS DSS can serve as managerial tools to assess the potential $R \& D$ project evaluation. This saves time, cost and delivers highly reliable output. The on-site visit shows that most R\&D projects lack financial and intellectual property data. This might affect the accuracy of the evaluation ranking.

\section{Implications and limitations}

This study provides the holistic R\&D commercialization capability criteria to assist entrepreneurs and researchers when faced with $R \& D$ commercialization decision. The criteria was developed from successful innovation cases; hence they enhance decision-making potential, provide a guideline of R\&D commercialization evaluation process, speed up the decision making process, and prevent risk of a resource meltdown and increase innovation exploitation.

This research is derived from samples form voluntary participants from the disclosed lists in the governmental research institutes. Although SEM results provide weight for each R\&D commercialization capability that would be the first step for developing the R\&D evaluation instrument and the longitudinal will need to investigate. Moreover artificial neural networks (ANN) might be considered to develop self-learning DSS from raw data.

The developed SEM-TOPSIS technique is suitable for innovative research projects whose goal is for use for commercial purposes because the indicators were analyzed from successful commercial $R \& D$ 
projects. Future research should study objectives in other areas such as academic, social, and public policy, the development of science and technology and so on.

\section{Acknowledgments}

So many people and several organizations have contributed to the completion of this project. I would like to express my gratitude to Chulalongkorn University 90th year scholarship program, which provided me with a scholarship. I would also like to thank all of my interviewees, who have spared their time to talk to me and shared with me their professional knowledge and experiences. Thank you very much.

\section{Reference}

Agostino, D., Arena, M., Azzone, G., Molin, M. D., \& Masella, C. (2012). Developing a performance measurement system for public research centres. Journal of Business Science and Applied Management, 7(1).

Amini, M., \& Bienstock, C. C. (2014). Corporate sustainability: an integrative definition and framework to evaluate corporate practice and guide academic research. Journal of Cleaner Production, 1-8.

Anooj, P. K. (2013). Implementing Decision Tree Fuzzy Rules in Clinical Decision Support System after Comparing with Fuzzy Based and Neural Network Based Systems. Paper presented at the International Conference on IT Convergence and Security (ICITCS), Macao.

Apperson, C., Arefzadeh, F., Dinsmore, A., Grabowski, R., May, D., Morandi, K., . . Jr., K. P. W. (2005)Project selection for technology investment. Systems and Information Engineering Design Symposium, 2005 IEEE

Banwet, D., \& Deshmukh, S. (2008). Evaluating performance of national R\&D organizations using integrated DEA-AHP technique. International journal of productivity and performance management, 57(5), 370-388.

Boyack, K. W., \& Rahal, N. (2005). Evaluation of Laboratory Directed Research and Development investment areas at Sandia. Technological Forecasting \& Social Change(72), 1122-1136. doi: 10.1016/j.techfore.2004.09.007

Büyüközkan, G., \& Çifçi, G. (2012). A novel hybrid MCDM approach based on fuzzy DEMATEL, fuzzy ANP and fuzzy TOPSIS to evaluate green suppliers. Expert Systems with Applications, 39, 3000-3011.

Byers, T. H., Dorf, R. C., \& Nelson, A. J. (2011). Technology ventures : from idea to enterprise. New York: McGraw-Hill.

Callen, J. L., Gavious, I., \& Segal, D. (2010). The complementary relationship between financial and non-financial information in the biotechnology industry and the degree of investor sophistication. Journal of Contemporary Accounting \& Economics(6), 61-76. doi: 10.1016/j.jcae.2010.09.001

Cardinaels, E., M.G., P., \& Veen-Dirks. (2010). Financial versus non-financial information: The impact of information organization and presentation in a Balanced Scorecard. Accounting, Organizations and Society(35), 565-578. doi: 10.1016/j.aos.2010.05.003

Chiesa, V., Frattini, F., Lazzarotti, V., \& Manzini, R. (2009). Performance measurement of research and development activities. European Journal of Innovation Management, 12(1), 25-61. doi: $10.1108 / 14601060910928166$

Coccia, M. (2003). Metrics of R\&D Performance and Management of Public Research Labs. IEEE.

Collan, M., \& Luukka, P. (2013). Evaluating R\&D Projects as Investments by Using an Overall Ranking from Four New Fuzzy Similarity Measure Based TOPSIS Variants. Fuzzy Systems, IEEE Transactions, $p p(99)$.

Frederick, H. H., \& Kuratko, D. F. (2010). Entrepreneurship (2nd ed.). Sydney: 2nd Asia-Pacific Edition. 
Gangurde, S. R., \& Akarte, M. M. (2013). Customer preference oriented product design using AHPmodified TOPSIS approach. Benchmarking: An International Journal of Business Science and Applied Management, 20(4), 549-564.

Gemünden, H. G., Salomo, S., \& Hölzle, K. (2007). Role Models for Radical Innovations in Times of Open Innovation. Creativity and Innovation Management, 16(4), 408-421. doi: 10.1111/j.14678691.2007.00451.x

Graettinger, C. P., Garcia-Miller, S., Siviy, J., Syckle, P. J. V., \& Schenk, R. J. (2002). Using the Technology Readiness Levels Scale to Support Technology Management in the DoD's ATD/STO Environments (A Findings and Recommendations Report Conducted for Army CECOM)

Han, S. Y., \& Bae, S. J. (2014). Internalization of R\&D outsourcing: An empirical study. International Journal of Production Economics. 105, 58-73.

Herath, H. S. B., \& Bremser, W. G. (2005). Real-option valuation of research and development investments: Implications for performance measurement. Managerial Auditing Journal, 20(1), 5572. doi: 10.1108/02686900510570704

Jungwook, B., Yunbae, K., Byungchul, L., Bodum, C., \& Chanmin, P. (2009). Analysis of the Factors to Affect Technology Transfer Fee in the Intellectual Property Management Paper presented at the Management of Engineering \& Technology, 2009. PICMET 2009., Portland, OR.

Karimi, M., Moztarzadeh, F., Pakzad, A., Beynaghi, A., \& Mozafari, M. (2012). Application of Fuzzy TOPSIS for Group Decision making in Evaluating Financial Risk Management. Paper presented at the International Conference on Innovation, Management and Technology Research (ICIMTR2012), 21-22 May, 2012, Malacca, Malaysia.

Kulatunga, U., Amaratunga, D., \& Haigh, R. (2007). Performance measurement in the construction research and development. International journal of productivity and performance management, 56(8), 673-688. doi: 10.1108/17410400710832994

Kulatunga, U., Amaratunga, D., \& Haigh, R. (2011). Structured approach to measure performance in construction research and development Performance measurement system development. International journal of productivity and performance management, 60(3), 289-310. doi: 10.1108/17410401111112005

Kwak, Y. H., \& Dixon, C. K. (2008). Risk management framework for pharmaceutical research and development projects. International Journal of Managing Projects in Business, 1(4), 552-565. doi: 10.1108/17538370810906255

Lazzarotti, V., RaffaellaManzini, \& LucaMari. (2011). A modelforR\&Dperformancemeasurement. Int. J.ProductionEconomics(134), 212-223. doi: 10.1016/j.ijpe.2011.06.018

Liang, W.-Y. (2003). The analytic hierarchy process in project evaluation: An R\&D case study in Taiwan. Benchmarking: An International Journal of Business Science and Applied Management, 10(5), 445 - 456.

Liao, C. H., Tseng, M. L., Lin, Y. H., \& Ho, P. L. (2007). The Synergetic Impact of Manufacturing Strategy Development on Operations-Based Non-Financial Performance. Paper presented at the Industrial Engineering and Engineering Management, Singapore.

Liberatore, M. J. (1987). An extension of the analytic hierarchy process for industrial R\&D project selection and resource allocation. Engineering Management, IEEE Transactions on Feb. 1987, 34(1), 12 - 18.

Lin, C.-T., \& Tsai, M.-C. (2008). Location choice for direct foreign investment in new hospitals in China by using ANP and TOPSIS. Quality \& Quantity, 44(2), 375-390

Liu, W., \& Shi, C. (2009). Research on Scientific Research Capability Evaluation Model of National defense University Based on TOPSIS. Paper presented at the Computational Intelligence and Software Engineering, 2009. CiSE 2009. International Conference on 11-13 Dec. 2009, Wuhan.

Miller, K., McAdam, R., Moffett, S., \& Brennan, M. (2011). An exploratory study of retaining and maintaining knowledge in university technology transfer processes. International Journal of Entrepreneurial Behaviour \& Research, 17(6), 663-684. doi: 10.1108/13552551111174729

Mohanty, R., Agarwal, R., Choudhury, A., \& Tiwari, M. (2005). A fuzzy ANP-based approach to R\&D project selection: a case study. International Journal of Production Research, 43(24), 5199-5216. 
Mu, J., \& Benedetto, C. A. D. (2011). Strategic orientations and new product commercialization: mediator, Moderator, and interplay. R\&D Management, 41(4), 337-359.

Nigro, G. L., Morreale, A., \& Enea, G. (2014). Open innovation: A real option to restore value to the biopharmaceutical R\&D. International Journal of Production Economics, 149, 183-193.

parsaeia, M., shahrakib, A., \& shahgholianc, K. (2014). Selecting the best responsive option to unexpected orders at the time of capacity-shortage using multi criteria decision models. Decision Science Letters, 3, 375-390.

Paun, F. (2011). Demand Readiness Level as equilibrium tool for the hybridization between Technology Push and Market Pull Approaches.

Plewa, C., Korff, N., \& Baaken, T. (2013). University-industry linkage evolution: an empirical investigation of relational success factors. $R \& D$ Management, 43(4), 365-380.

Popaitoon, S., \& Siengthai, S. (2014). The moderating effect of human resource management practices on the relationship between knowledge absorptive capacity and project performance in projectoriented companies. Internation journal of project management, 32, 908-920.

Punniyamoorty, M., Mathiyalagan, P., \& Lakshmi, G. (2012). A combined application of structural equation modeling (SEM) and analytic hierarchy process (AHP) in supplier selection. Benchmarking: An International Journal, 19(1), 70-92.

Raymond, L., \& St-Pierre, J. (2010). R\&D as a determinant of innovation in manufacturing SMEs: An attempt at empirical clarification. Technovation, 30(1), 48-56. doi: 10.1016/j.technovation.2009.05.005

Saaty, T. L. (1996). Decision making with dependence and feedback: The analytic network process (Vol. 4922): RWS publications Pittsburgh.

Salehi, K. (2015). A hybrid fuzzy MCDM approach for project selection problem. Decision Science Letters, 4(1), 109-116.

Seebode, D., Jeanrenaud, S. \& Bessant, J. (2012). Managing innovation for sustainability. $R \& D$ Management, 42(3), 195-206.

Singh, H., \& Kumar, R. (2013). Hybrid methodology for measuring the utilization of advanced manufacturing technologies using AHP and TOPSIS. Benchmarking: An International Journal of Business Science and Applied Management, 20(2), 169-185.

Sohn, S. Y., Joo, Y. G. \& Han, H. K. (2007). Structural equqtion model for the evaluation of national funding on R\&D project of SMEs in consideration with MBNQA criteria. Evaluation and Program Planning, 30, 10-20.

Somsuk, N., Punnakitikashem, P., \& Laosirihongthong, T. (2010). Determining Enabling Factors of University Technology Business Incubation Program: Resource-Based View Theory. Paper presented at the Industrial Engineering and Engineering Management (IEEM), Macao.

Stanley, R., Lillis, K. A., Zuspan, S. J., Lichenstein, R., Ruddy, R. M., Gerardi, M. J., . . (PECARN), t. P. E. C. A. R. N. (2010). Development and implementation of a performance measure tool in an academic pediatric research network. Contemporary Clinical Trials(31), 429-437. doi: 10.1016/j.cct.2010.05.007

Tan, Y.-t., Shen, L.-y., Langston, C., \& Liu, Y. (2010). Construction project selection using fuzzy TOPSIS approach. Journal of Modelling in Management, 5(3), 302-315.

Teece, D. J. (2010). Forward Integration and Innovation: Transaction Costs and Beyond .Journal of Retailing 86(3), 277-283.

Tidd, J., \& Besssant, J. (2009). Managing Innovation. Chichester: Johm Wiley \& Sons Ltd.

Thailand National science technology and innovation policy office.(2013). Review of the Thailand competitiveness. Retrieved September, 2013, from http://www.sti.or.th

United States Department of Energy. (2011.). Technology Readiness Assessment Guide (DOE G 413.3-4).

Vandaele, N. J., \& Decouttere, C, J. (2013). Sustainable R\&D portfolio assessment. Decision Support Systems, 54(4), 1521-1532. 
Verbano, C., \& Nosella, A. (2010). Addressing R\&D investment decisions: a cross analysis of R\&amp;D project selection methods. European Journal of Innovation Management, 13(3), 355379. doi: 10.1108/14601061011060166

Wang, K., Wang, C. K., \& Hu, C. (2005). Analytic hierarchy process with fuzzy scoring in evaluating multidisciplinary R\&D projects in China. Engineering Management, IEEE Transactions on, 52(1), 119-129.

Wernerfelt, B. (1984). A resource-based view of the firm. . Strategic Management Journal, 5, 171-180.

Yongjian, K., Xinping, L., \& Shouqing, W. (2008). Equitable Financial Evaluation Method for PublicPrivate Partnership Projects. TSINGHUA SCIENCE AND TECHNOLOGY, 13(5), 702-707. doi: 10.1016/S1007-0214(08)70111-1

Yoon, P., \& Hwnag, C.-L. (1995). Multiple Attribute Decision Making an Introduction. CA: Sage.

Yu, T., Zhou, J., Zhao, K., Wang, W., \& Wang, W. (2008). Study on Project Experts' Evaluation Based on Analytic Hierarchy Process and Fuzzy Comprehensive Evaluation. Paper presented at the Intelligent Computation Technology and Automation (ICICTA), 2008 International Conference on 20-22 Oct. 2008, Hunan. 
Appendix A

Selection R\&D evaluation criteria and indicators and IOC score (IOC $>0.5=$ Pass)

\begin{tabular}{|c|c|c|c|c|c|c|c|c|}
\hline \multirow[t]{2}{*}{ Criteria } & \multirow[t]{2}{*}{ Items } & \multicolumn{5}{|c|}{ IOC score (5 experts) } & \multirow[b]{2}{*}{ total } & \multirow[t]{2}{*}{ decision } \\
\hline & & 1 & 2 & 3 & 4 & 5 & & \\
\hline \multirow[t]{8}{*}{ Technology } & Preliminary study & +1 & +1 & +1 & +1 & 0 & 0.8 & Pass \\
\hline & Newness & 0 & +1 & +1 & +1 & +1 & 0.8 & Pass \\
\hline & Comparative advantage & +1 & +1 & +1 & +1 & +1 & 1 & Pass \\
\hline & Technology life cycle & +1 & -1 & -1 & +1 & 0 & 0 & Fail \\
\hline & Technology readiness level & +1 & +1 & +1 & +1 & 0 & 0.8 & Pass \\
\hline & Compatibility with existing technology & +1 & +1 & +1 & +1 & 0 & 0.8 & Pass \\
\hline & Standards and regulation & +1 & +1 & +1 & +1 & +1 & 1 & Pass \\
\hline & Research facilitation & +1 & +1 & -1 & +1 & -1 & 0.2 & Fail \\
\hline \multirow{5}{*}{$\begin{array}{l}\text { Intellectual } \\
\text { property : IP }\end{array}$} & Patentability & 0 & -1 & 0 & +1 & 0 & 0 & Fail \\
\hline & Level of Protection & 0 & -1 & +1 & +1 & 0 & 0.2 & Fail \\
\hline & Types of Intellectual Property rights & 0 & -1 & 0 & +1 & 0 & 0 & Fail \\
\hline & Upfront & 0 & +1 & 0 & +1 & +1 & 0.6 & Pass \\
\hline & Royalty Fee & 0 & +1 & 0 & +1 & +1 & 0.6 & Pass \\
\hline \multirow[t]{11}{*}{ Marketing } & Market Trend & 0 & +1 & 0 & +1 & +1 & 0.6 & Pass \\
\hline & Market share & +1 & 0 & +1 & +1 & 0 & 0.6 & Pass \\
\hline & Market Growth & 0 & +1 & 0 & +1 & +1 & 0.6 & Pass \\
\hline & Market Target & +1 & +1 & +1 & +1 & 0 & 0.8 & Pass \\
\hline & Competitor analysis & +1 & +1 & +1 & +1 & +1 & 1 & Pass \\
\hline & Business plan & +1 & 0 & +1 & 0 & 0 & 0.4 & Fail \\
\hline & Market Strategy & +1 & +1 & +1 & +1 & +1 & 1 & Pass \\
\hline & Process improvement & 0 & +1 & +1 & +1 & +1 & 0.8 & Pass \\
\hline & Marketing mix & +1 & 0 & +1 & +1 & 0 & 0.6 & Pass \\
\hline & 5 Force models & +1 & +1 & 0 & +1 & 0 & 0.6 & Pass \\
\hline & SWOT & +1 & 0 & +1 & +1 & 0 & 0.6 & Pass \\
\hline \multirow[t]{8}{*}{ Finance } & Product price & +1 & +1 & +1 & +1 & +1 & 1 & Pass \\
\hline & Budget details & +1 & 0 & +1 & +1 & 0 & 0.6 & Pass \\
\hline & Cash flow & +1 & 0 & +1 & +1 & +1 & 0.8 & Pass \\
\hline & Break-even point & +1 & +1 & +1 & +1 & +1 & 1 & Pass \\
\hline & Payback period & +1 & +1 & 0 & +1 & +1 & 0.8 & Pass \\
\hline & Net Present Value: NPV & +1 & 0 & 0 & +1 & +1 & 0.6 & Pass \\
\hline & Internal Rate of Return: IRR & +1 & +1 & 0 & +1 & 0 & 0.6 & Pass \\
\hline & Benefit Cost Ratio & +1 & +1 & 0 & +1 & 0 & 0.6 & Pass \\
\hline \multirow[t]{7}{*}{ Resource } & $\begin{array}{l}\text { Project member profiles: Knowledge and } \\
\text { experience }\end{array}$ & +1 & -1 & +1 & +1 & +1 & 0.6 & Pass \\
\hline & Multidisciplinary team & +1 & +1 & +1 & +1 & +1 & 1 & Pass \\
\hline & Business experience & 0 & +1 & 0 & +1 & +1 & 0.6 & Pass \\
\hline & $\begin{array}{l}\text { Product development process } \\
\text { understanding }\end{array}$ & +1 & +1 & +1 & +1 & 0 & 0.8 & Pass \\
\hline & Enthusiasm and Ambition & +1 & +1 & 0 & +1 & 0 & 0.6 & Pass \\
\hline & Good governance & 0 & +1 & -1 & +1 & -1 & 0 & Fail \\
\hline & Risk management & +1 & -1 & -1 & +1 & 0 & 0 & Fail \\
\hline \multirow[t]{6}{*}{ Impact } & Social impact & +1 & 0 & +1 & +1 & +1 & 0.8 & Pass \\
\hline & Economic impact & +1 & 0 & +1 & +1 & +1 & 0.8 & Pass \\
\hline & Environment impact & +1 & +1 & +1 & +1 & +1 & 1 & Pass \\
\hline & Innovation capacity & +1 & +1 & 0 & +1 & +1 & 0.8 & Pass \\
\hline & Innovation linkages & 0 & +1 & 0 & +1 & +1 & 0.6 & Pass \\
\hline & R\&D users satisfaction & 0 & +1 & 0 & +1 & +1 & 0.6 & Pass \\
\hline
\end{tabular}




\section{Appendix B}

\section{Sample characteristic}

\begin{tabular}{|c|c|c|c|c|c|c|c|}
\hline Variable & attribute & $\begin{array}{l}\text { Entrepreneur } \\
\text { person }\end{array}$ & percentage & $\begin{array}{l}\text { researcher } \\
\text { person }\end{array}$ & percentage & $\begin{array}{l}\text { Total } \\
\text { person }\end{array}$ & percentage \\
\hline Information source & & 226 & 83.1 & 46 & 16.9 & 272 & 100.0 \\
\hline \multirow[t]{2}{*}{ Gender } & male & 139 & 61.5 & 25 & 54.35 & 164 & 60.3 \\
\hline & female & 87 & 38.5 & 21 & 45.65 & 108 & 39.7 \\
\hline \multirow[t]{4}{*}{ Education } & Undergraduate & 16 & 7.1 & - & - & $\lfloor 6$ & 5.9 \\
\hline & bachelor's degree & 110 & 48.6 & - & - & 110 & 40.5 \\
\hline & Master degree & 85 & 37.7 & 13 & 28.26 & 98 & 36.0 \\
\hline & Doctoral Degree & 15 & 6.6 & 33 & 71.74 & 48 & 17.6 \\
\hline \multirow[t]{4}{*}{ Work experience } & Lower 10 years & 36 & 15.9 & 14 & 30.44 & 50 & 18.4 \\
\hline & 10-15 years & 70 & 31.0 & 13 & 28.26 & 83 & 30.5 \\
\hline & 16-20 years & 48 & 21.3 & 8 & 17.39 & 56 & 20.6 \\
\hline & More than 20 years & 72 & 31.8 & 11 & 23.91 & 83 & 30.5 \\
\hline \multirow[t]{15}{*}{ Industrial sectors } & Food and drugs & 46 & 20.4 & - & - & 46 & 20.4 \\
\hline & Fashion & 17 & 7.5 & - & - & 17 & 7.5 \\
\hline & Agriculture & 43 & 19.0 & - & - & 43 & 19.0 \\
\hline & Electronic & 13 & 5.8 & - & - & 13 & 5.8 \\
\hline & Petroleum & 2 & .9 & - & - & 2 & .9 \\
\hline & Construction & 8 & 3.5 & - & - & 8 & 3.5 \\
\hline & Auto Mobil & 15 & 6.6 & - & - & 15 & 6.6 \\
\hline & Machinery & 17 & 7.5 & - & - & 17 & 7.5 \\
\hline & Paper and printing & 5 & 2.2 & - & - & 5 & 2.2 \\
\hline & Material & 14 & 6.2 & - & - & 14 & 6.2 \\
\hline & Software & 15 & 6.6 & - & - & 15 & 6.6 \\
\hline & Medical & 13 & 5.8 & - & - & 13 & 5.8 \\
\hline & Wood & 3 & 1.3 & - & - & 3 & 1.3 \\
\hline & Energy & 6 & 2.7 & - & - & 6 & 2.7 \\
\hline & All sectors & 226 & 100.0 & - & - & 226 & 100.0 \\
\hline \multirow[t]{4}{*}{ Innovation level } & Organization & 45 & 19.9 & 4 & 8.7 & 49 & 18.0 \\
\hline & Country & 157 & 69.5 & 32 & 69.6 & 189 & 69.5 \\
\hline & Global & 19 & 8.4 & 10 & 21.7 & 29 & 10.7 \\
\hline & Other & 5 & 2.2 & - & - & 5 & 1.8 \\
\hline
\end{tabular}

Age $\bar{X}=39.51 \quad \mathrm{~s}=10.25$

Capital stock )million bath $(\bar{X}=181.31 \quad \mathrm{~s}=1081.98$ (Range $=0.1-9150)$

employee (person $(\bar{X}=293.93 \mathrm{~s}=1108.00(($ Range $=2-10000)$

Annual sales )million bath( $\bar{X}=26910.03 \mathrm{~s}=35738.67$ (Range $=0.06-300,000$ )

R\&D budget )million bath $(\bar{X}=34.26 \quad \mathrm{~s}=10.29$ (Range $=0-3000)$

Number of R\&D $\bar{X}=7.83 \quad \mathrm{~s}=7.02$ (Range $=0-285)$

Number of new product from R\&D/NPD per year $\bar{X}=3.80 \quad \mathrm{~s}=7.38$ (Rank $=0$ - 285) 


\section{Appendix C}

SEM-TOPSIS score from accuracy test

\begin{tabular}{|c|c|c|c|c|}
\hline No. & result & project & Score & organization \\
\hline 1 & $\mathrm{C}$ & SMMS & 0.50 & \multirow{3}{*}{$\begin{array}{l}\text { Weapon Production } \\
\text { Center }\end{array}$} \\
\hline 2 & $\mathrm{C}$ & Link Analysis & 0.60 & \\
\hline 3 & I & Mobile App & 0.20 & \\
\hline 4 & $\mathrm{C}$ & Farm 1 & 0.40 & \multirow[t]{3}{*}{ Worldwide Thana } \\
\hline 5 & $\mathrm{C}$ & Farm 2 & 0.62 & \\
\hline 6 & $\mathrm{C}$ & Compressor & 0.61 & \\
\hline 7 & $\mathrm{C}$ & Traffic light color & 0.91 & \multirow[t]{3}{*}{$3 \mathrm{M}$} \\
\hline 8 & $\mathrm{C}$ & Electronic tape & 0.89 & \\
\hline 9 & $\mathrm{C}$ & Electronic equipment cleaner & 0.78 & \\
\hline 10 & $\mathrm{C}$ & my car & 1.00 & \multirow[t]{2}{*}{ Senior Com } \\
\hline 11 & $\mathrm{C}$ & $\mathrm{H}$ meter & 0.61 & \\
\hline 12 & C & Anti-mosquito shirt & 0.50 & \multirow[t]{3}{*}{ THTI } \\
\hline 13 & $\mathrm{C}$ & Pineapple fiber cloth & 0.64 & \\
\hline 14 & $\mathrm{C}$ & Natural dye colors & 0.24 & \\
\hline 15 & $\mathrm{C}$ & Night Cream extract & 0.78 & \multirow[t]{2}{*}{ TISTR } \\
\hline 16 & $\mathrm{C}$ & Gac sauce & 0.21 & \\
\hline 17 & $\mathrm{C}$ & Silver Nano & 0.63 & \multirow[t]{3}{*}{ IPChula } \\
\hline 18 & $\mathrm{C}$ & Anti-bacterial mask & 0.56 & \\
\hline 19 & $\mathrm{C}$ & Anti-bacterial capsule & 0.40 & \\
\hline 20 & $\mathrm{C}$ & Silver Nano & 0.72 & \multirow[b]{3}{*}{ (2nd users) } \\
\hline 21 & $\mathrm{C}$ & Anti-bacterial mask & 0.71 & \\
\hline 22 & $\mathrm{C}$ & Anti-bacterial capsule & 0.29 & \\
\hline 23 & $\mathrm{C}$ & COSD & 0.87 & \multirow[t]{3}{*}{ GIB } \\
\hline 24 & $\mathrm{C}$ & COSW & 0.76 & \\
\hline 25 & $\mathrm{C}$ & MAC & 0.97 & \\
\hline 26 & $\mathrm{C}$ & Palm Extracts & 0.94 & \multirow[t]{4}{*}{ ARDA } \\
\hline 27 & $\mathrm{C}$ & Sweet rice & 0.58 & \\
\hline 28 & $\mathrm{C}$ & Moth-killing machine & 0.94 & \\
\hline 29 & $\mathrm{C}$ & Rice Bran & 0.14 & \\
\hline 30 & $\mathrm{C}$ & PMG & 0.50 & \multirow{16}{*}{$\begin{array}{l}\text { Faculty of engineering } \\
\text { Chulalongkorn } \\
\text { University }\end{array}$} \\
\hline 31 & $\mathrm{C}$ & Cilicone mould castion & 0.52 & \\
\hline 32 & $\mathrm{C}$ & Titaniun casting & 0.40 & \\
\hline 33 & $\mathrm{C}$ & Spray dried & 0.419 & \\
\hline 34 & $\mathrm{C}$ & Packaging Film & 0.483 & \\
\hline 35 & $\mathrm{C}$ & Wastewater & 0.412 & \\
\hline 36 & $\mathrm{C}$ & Modification of human bone graph & 0.571 & \\
\hline 37 & $\mathrm{C}$ & Sterling silver & 0.691 & \\
\hline 38 & $\mathrm{C}$ & Fire resistance concrete wall & 0.528 & \\
\hline 39 & $\mathrm{C}$ & Motor Cleaner & 0.482 & \\
\hline 40 & $\mathrm{C}$ & Memory polymers & 0.502 & \\
\hline 41 & $\mathrm{C}$ & Nuclear & 0.419 & \\
\hline 42 & $\mathrm{C}$ & Wheel chair & 0.573 & \\
\hline 43 & $\mathrm{C}$ & Claim di & 0.678 & \\
\hline 44 & $\mathrm{C}$ & Chitosan & 0.703 & \\
\hline 45 & $\mathrm{C}$ & Detector & 0.407 & \\
\hline
\end{tabular}

$\mathrm{C}=$ Correct, $\mathrm{I}=$ Incorrect 